\title{
ANALISIS MUTU MINYAK ATSIRI BUNGA CENGKEH (Syzygium aromaticum (L.) Meer. \& Perry) DARI MALUKU, SUMATERA, SULAWESI DAN JAWA DENGAN METODE METABOLOMIC BERBASIS GC-MS
}

\section{QUALITY ANALYSIS OF CLOVE BUD ESSENTIAL OILS (Syzygium aromaticum (L.) Meer. \& Perry) FROM MALUKU, SUMATERA, SULAWESI AND JAVA WITH METABOLOMIC BASED ON GC-MS METHOD}

\author{
Rizky Farah Megawati, Muhammad Da'i, Rima Munawaroh* \\ Fakultas Farmasi, Universitas Muhammadiyah Surakarta \\ safirasyifa@yahoo.com
}

\begin{abstract}
ABSTRAK
Cengkeh (Syzygium aromaticum (L.) Meer. \& Perry) merupakan salah satu tanaman penghasil minyak atsiri. Mutu minyak cengkeh ditentukan oleh sifat fisik dan kandungan metabolit. Penelitian ini dilakukan bertujuan untuk mengetahui metabolit yang ada di dalam minyak kuncup bunga cengkeh dari Maluku, Sumatera, Sulawesi, dan Jawa. Kuncup bunga cengkeh kering didestilasi uap dan air. Destilasi direplikasi 3 kali untuk setiap daerah. Minyak atsiri diuji indeks bias, organoleptis, bobot jenis dan dianalisis menggunakan GC-MS dengan kolom Rxi ${ }^{T M}-1 M S$, flow rate helium $5,3 \mathrm{~mL} /$ menit, dengan temperature programming $50-245^{\circ} \mathrm{C}$ (kenaikan $10^{\circ} \mathrm{C} /$ menit). Penentuan metabolit dilakukan dengan cara membandingkan spektra massa sampel dengan internal Willey Library. Hasil yang diperoleh dianalisis menggunakan metode analisis Cluster. Pengelompokan didasarkan pada keberadaan senyawa dan \%area masing-masing senyawa. Hasil penelitian menunjukkan minyak atsiri bunga cengkeh dari Maluku dan Jawa mempunyai metabolit yang lebih banyak dan mempunyai kadar senyawa mayor yang lebih tinggi dibanding minyak atsiri bunga cengkeh dari Sumatera dan Sulawesi.
\end{abstract}

Kata kunci: Cengkeh (Syzygium aromaticum (L.) Meer. \& Perry), metabolit, kuncup bunga, GCMS.

\section{ABSTRACT}

Clove (Syzygium aromaticum (L.) Meer. \& Perry) is one of plant produce essential oil. The quality of clove oil is determined by physical properties and metabolite content. This research was conducted to find metabolite content in clove bud oil from Maluku, Sumatera, Sulawesi, and Java. Dried clove buds was distilled by steam and water. Destillation replicated three times for each region. Essential oil are tested for refractive index, organoleptic, specific gravity and analyzed using GC-MS with $R x i^{T M}-1 M S$ column, helium flow rate $5,3 \mathrm{~mL} / \mathrm{min}$, temperature programming $50-245^{\circ} \mathrm{C}$ $\left(10^{\circ} \mathrm{C} /\right.$ minutes increase). Determination of metabolite was done by comparing the mass spectra of sample with internal Wiley Library. The result were analyzed using cluster analysis methods. The grouping is based on the presence of compounds and \% area of each compound. The result showed that clove bud essential oils from Maluku and Java have more metabolite content and major compound was higher than clove bud essential oils from Sumatera and Sulawesi.

Keywords: Clove (Syzygium aromaticum (L.) Meer. \& Perry), metabolites, buds, GC-MS.

\section{PENDAHULUAN}

Minyak cengkeh memiliki banyak metabolit yang bermanfaat bagi manusia. Secara tradisional minyak cengkeh digunakan untuk obat sakit gigi. Metabolit cengkeh yang paling banyak adalah eugenol, eugenol asetat, dan kariofilen. Senyawa-senyawa tersebut mempunyai sifat sebagai antibakteri dan antijamur (Ayoola et al., 2008). Eugenol, isoeugenol, dan zat vanili dalam minyak atsiri cengkeh dipakai pada industri kimia sebagai zat dasar untuk menyusun bermacam-macam jenis persenyawaan (Anonim, 1991). Turunan eugenol atau turunan metoksifenol secara besar-besaran digunakan dalam parfum, perasa (flavoring), formulasi obat oles anti nyamuk, penyerap UV, analgetik, bioside, antiseptik, stabilisator dan antioksidan pembuatan plastik dan karet (Lee dan Shibamoto, 2001 cit Alma et al., 2007). Minyak cengkeh mempunyai aktivitas biologi sebagai antivirus terhadap virus hepatitis $C$ (Hussein et al., 2000 cit Chaieb et al., 2007). Eugenin yang ada di dalam minyak atsiri cengkeh diidentifikasi sebagai senyawa anti-HSV (Kurokawa et al., 1998 cit Chaieb et al., 2007). 
Cinamaldehyde dari minyak cengkeh dapat mereduksi mutagenesis yang diinduksi UV sebagus mutagenesis yang induksi oleh furylfuramide (AF-2) dalam E. Coli WP2s (Ohta et al., 1983 cit Chaieb et al., 2007).

Mutu minyak atsiri sangat ditentukan oleh sifat dan senyawa kimia yang terkandung di dalamnya dan belum ada penelitian mengenai hal ini. Selama ini mutu minyak atsiri didasarkan pada sifat fisik seperti bobot jenis, indeks bias, putaran optik, dan kelarutan di dalam etanol $70 \%$. Penentuan mutu berdasarkan kandungan metabolit dalam minyak atsiri sangat penting untuk mengetahui secara umum komponen kimia yang terdapat di dalamnya. Komposisi kimia minyak atsiri akan menentukan nilai dan kegunaan minyak atsiri tersebut (Ketaren, 1985). Penelitian ini dilakukan untuk memberikan gambaran mengenai metabolit dalam minyak cengkeh dari daerah di Pulau Sumatera, Sulawesi, Maluku, dan Jawa yang berhubungan dengan mutu minyak cengkeh yang diperoleh dengan destilasi uap dan air.

\section{METODOLOGI PENELITIAN Alat dan Bahan}

Alat yang digunakan adalah destilator uap dan air, alat gelas, GCMS Shimadzu-GC 2010 dengan mass selective detector dengan kolom $\mathrm{Rxi}^{\mathrm{TM}}-1 \mathrm{MS}$, piknometer, refraktometer Abbe.

Bahan yang digunakan adalah bunga cengkeh kering dari Pulau Maluku (daerah Amboyna), Pulau Sumatera (daerah Padang), Pulau Sulawesi (daerah Palopo), Pulau Jawa (daerah Tawangmangu), aquadest, $\mathrm{Na}_{2} \mathrm{SO}_{4}$ eksikatus, aseton, etanol $70 \%$, gas helium, metanol p.a.

\section{Jalannya Penelitian \\ Pengumpulan Bunga Cengkeh}

Bunga cengkeh yang digunakan pada penelitian ini adalah bunga cengkeh kering yang diambil dari perkebunan cengkeh di Pulau Maluku, Sumatera, Sulawesi, dan Jawa.

\section{Isolasi Minyak Atsiri Kuncup Bunga Cengkeh}

Ditimbang kuncup bunga cengkeh kering sebanyak 75 gram, dimasukkan ke dalam angsang dandang alumunium yang telah dilapisi kertas saring dan diisi aquadest secukupnya, kuncup bunga cengkeh diperciki aquadest secukupnya, dandang alumunium ditutup rapat. Rangkaian alat destilasi dipasang dan air dialirkan melalui pendingin selama proses destilasi. Bunga cengkeh dipanaskan dengan kompor gas sampai minyak keluar dan tertampung pada tempat penampung berskala.
Destilasi dihentikan setelah tidak ada minyak yang tertampung pada tempat penampung berskala. Minyak yang diperoleh dipisahkan dengan air menggunakan corong pisah, dimasukkan $\mathrm{Na}_{2} \mathrm{SO}_{4}$ eksikatus ke dalam minyak untuk mengikat sisa air. Minyak atsiri yang diperoleh disimpan dalam botol berwarna gelap dan ditutup rapat. Destilasi dilakukan sebanyak 3 kali untuk masing-masing daerah.

\section{Pemeriksaan Organoleptis Minyak Atsiri Kuncup Bunga Cengkeh}

Pemeriksaan warna, rasa dan bau terhadap minyak kuncup bunga cengkeh Syzygium aromaticum (L) Meer.\& Perry dari hasil destilasi uap dan air.

\section{Pemeriksaan Bobot Jenis Minyak Atsiri Kuncup Bunga Cengkeh}

Untuk menetapkan bobot jenis minyak atsiri kuncup bunga cengkeh digunakan piknometer $25 \mathrm{~mL}$ suhu percobaan $25^{\circ} \mathrm{C}$ dengan 4 kali replikasi pembacaan. Bobot jenis minyak atsiri merupakan perbandingan bobot minyak atsiri terhadap bobot air pada suhu yang sama (Guenter, 1987).

\section{Pemeriksaan Indeks Bias Minyak Atsiri Kuncup Bunga Cengkeh \\ Penetapan indeks bias minyak atsiri} kuncup bunga cengkeh dilakukan dengan menggunakan refraktometer Abbe. Nilai indeks bias dapat langsung dibaca pada alat. Sebagai kontrol digunakan air suling dengan pengerjaan sama seperti diatas (Guenter, 1987).

\section{Analisis Minyak Atsiri Kuncup Bunga Cengkeh menggunakan GC-MS \\ Analisis minyak atsiri dilakukan} menggunakan Shimadzu-GC 2010 dilengkapi dengan Shimadzu-GCMS $2010 \mathrm{~S}$ mass selective detector dan kolom kapiler $\mathrm{Rxi}^{\mathrm{TM}}-1 \mathrm{MS}$ (30 m x 0,25 mm, ketebalan lapisan 0,25 $\mu \mathrm{m}$ ). Detektor MS menggunakan metode ionisasi bombardement electron pada energi $70 \mathrm{eV}$. Gas pembawa yang digunakan adalah Helium dengan laju alir 5,3 $\mathrm{mL} /$ menit. Injektor dan $M S$ transfer line suhunya masing-masing diatur pada 280 dan $245^{\circ} \mathrm{C}$. Temperatur kolom dijaga pada $50^{\circ} \mathrm{C}$ lalu secara perlahan ditingkatkan sampai $245^{\circ} \mathrm{C}$ dengan laju peningkatan $10^{\circ} \mathrm{C} /$ menit. Satu $\mu \mathrm{L}$ sampel dilarutkan metanol p.a $(2,5 \%$ b/v $)$ diinjeksikan secara manual menggunakan splitless mode. Komponen diidentifikasi dengan membandingkan spektra massa sampel dengan internal Willey Library. Replikasi pengukuran dilakukan $3 \mathrm{X}$ dengan replikasi pembacaan $2 X$. 


\section{Analisis Data}

Data rendemen dianalisis menggunakan uji Kruskal-Wallis dan Mann-Whitney, sedangkan data yang diperoleh pada analisis minyak atsiri kuncup bunga cengkeh dengan GCMS berupa berat molekul dan pola fragmentasi yang menunjukkan jenis metabolit, dan intensitas peak yang menunjukkan kadar. Data hasil penelitian yang diperoleh dianalisa menggunakan metode analisis Cluster. Data hasil yang diperoleh dianalisis Cluster menggunakan program SPSS. Pengelompokan data berdasarkan keberadaan senyawa dan \% area.

\section{HASIL DAN PEMBAHASAN \\ Hasil Isolasi Minyak Atsiri Kuncup Bunga Cengkeh}

Rendemen yang diperoleh pada penyulingan minyak bunga cengkeh dari Maluku sebanyak $15,21 \pm 0,40$, rendemen minyak bunga cengkeh dari Sumatera sebanyak 15,05 $\pm 0,40$, rendemen minyak bunga cengkeh dari Sulawesi sebanyak 14,14 $\pm 0,00$ dan rendemen minyak bunga cengkeh dari Jawa sebanyak $14,09 \pm 0,00$. Perbedaan rendemen tersebut dapat dipengaruhi oleh perbedaan daerah dan penanganan bahan. Karakteristik minyak atsiri kuncup bunga cengkeh yang diperoleh dari keempat daerah adalah kuning muda-jernih, bau khas aromatik, rasa pedas, agak pahit.

Data rendemen dianalisis menggunakan Shapiro-Wilk dan dilanjutkan uji Kruskal-Wallis dengan Post Hoc Mann Whitney. Hasil analisis rendemen kuncup bunga cengkeh dari keempat daerah berbeda signifikan, kecuali rendemen kuncup bunga cengkeh dari Maluku dan Sumatera, sehingga dapat dikatakan rendemen kuncup bunga cengkeh dari Maluku dan Sumatera sama besar.

\section{Hasil Pemeriksaan Bobot Jenis Minyak Atsiri Kuncup Bunga Cengkeh}

Hasil pengujian bobot jenis terkoreksi suhu $25^{\circ} \mathrm{C} / 25^{\circ} \mathrm{C}$ minyak atsiri bunga cengkeh Maluku sebesar 1,0533 $\pm 0,0014$ minyak cengkeh Sumatera $1,0583 \pm 0,0024$ minyak cengkeh Sulawesi $1,0605 \pm 0,0032$ dan minyak cengkeh Jawa $1,0570 \pm 0,0032$. Hasil pengujian bobot jenis dari keempat daerah masuk dalam range bobot jenis minyak atsiri bunga cengkeh suhu $25^{\circ} \mathrm{C} / 25^{\circ} \mathrm{C}$ yang tercantum dalam SNI yaitu 1,030-1,060. Berdasarkan hasil tersebut dapat disimpulkan minyak atsiri kuncup bunga cengkeh (Syzygium aromaticum (L.) Meer. \& Perry) yang didapat dari destilasi uap dan air merupakan minyak atsiri yang murni.
Hasil Pemeriksaan Indeks Bias Minyak Atsiri Kuncup Bunga Cengkeh

Hasil pengujian indeks bias terkoreksi minyak atsiri bunga cengkeh Maluku sebesar $1,5272 \pm 0,0000$ minyak cengkeh Sumatera $1,5314 \pm 0,0000$ minyak cengkeh Sulawesi $1,5300 \pm 0,0003$ dan minyak cengkeh Jawa $1,5308 \pm 0,0002$. Hasil pengujian indeks bias dari keempat daerah masuk dalam range indeks bias minyak atsiri bunga cengkeh yang tercantum dalam SNI yaitu 1,527-1,535. Berdasarkan hasil tersebut dapat disimpulkan minyak atsiri kuncup bunga cengkeh (Syzygium aromaticum (L.) Meer. \& Perry) yang didapat dari destilasi uap dan air merupakan minyak atsiri yang murni.

\section{Hasil Analisis Minyak Atsiri Kuncup Bunga Cengkeh menggunakan GC-MS}

Hasil analisis GC-MS minyak atsiri kuncup bunga cengkeh dari Maluku dan Jawa diperoleh 9 peak, dari Sumatera diperoleh 7 peak dan dari Sulawesi diperoleh 6 peak.

Berdasar tabel 1. dapat diketahui bahwa minyak atsiri kuncup bunga cengkeh dari Maluku terdiri dari 9 senyawa yaitu $p$ eugenol; 3-allilguaiakol; trans(beta)-kariofilen; 3,4-dimetilbisiklo[4.3.0]nona-3,8-dien-7-on; alfahumulen; eugenol asetat; asam propanedioat, dibromo-bis(trimetilsilil)ester; 2,3,4trimetoksiasetofenon dan satu senyawa yang tidak dapat diidentifikasi. Minyak atsiri kuncup bunga cengkeh dari Sumatera terdiri dari 7 senyawa yaitu 3-allilguaiakol; trans(beta)kariofilen; 3,4-dimetilbisiklo[4.3.0]nona-3,8-dien7-on; alfa-humulen; eugenol asetat; asam propanedioat,dibromo-bis(trimetilsilil)este dan etanone, 1-(3,4,5-trimetoksifenil). Minyak atsiri kuncup bunga cengkeh dari Sulawesi terdiri dari 6 senyawa yaitu 3-allilguaiakol; trans(beta)kariofilen; 3,4-dimetilbisiklo[4.3.0]nona-3,8-dien7-on; alfa-humulen; eugenol asetat dan (-)-akopaen. Minyak atsiri kuncup bunga cengkeh dari Jawa terdiri dari 9 senyawa yaitu $p$ eugenol; 3-allilguaiakol; trans(beta)-kariofilen; 3,4-dimetilbisiklo[4.3.0]nona-3,8- dien-7-on; alfa-humulen; eugenol asetat; asam propanedioat,dibromo-bis(trimetilsilil)ester; etanone,1-(2,4,6-trimetoksifenil) dan 3trideuterometoksi-4-asetil-2(5H)-furanon.

Komponen mayor penyusun minyak atsiri kuncup bunga cengkeh dari keempat daerah adalah sama, sedangkan komponen minor penyusun minyak atsiri kuncup bunga cengkeh dari keempat daerah berbeda-beda. Komponen mayor penyusun minyak atsiri dari keempat daerah yaitu eugenol dengan bentuk $p$-eugenol dan 3-allilguaiakol, beta-kariofillen, alfahumulen, dan eugenol asetat. Eugenol dan 
eugenol asetat mempunyai peranan sebagai antibakteri, antijamur, antioksidan, bahan baku parfum, perasa, analgetik, stabilisator, dan bioside (Anonim, 1991; Lee dan Shibamoto, 2001 cit Alma et al, 2007). Beta-kariofillen dapat digunakan sebagai anestesi lokal, dietary canabioid, dan sebagai induktor detoksifikasi enzim S-transferase dalam liver dan usus (Ghelardini et al, 2001; Gertsch et al 2008; Zheng et al 1992). Komponen minor seperti 2,3,4-trimetoksiasetofenon tidak mempunyai peranan biologis tetapi dapat digunakan sebagai starting material sintesis senyawa.

Tabel 1- Profil Kimia dan \%Area Komponen Minyak Atsiri Bunga Cengkeh

\begin{tabular}{|c|c|c|c|c|c|c|c|c|c|c|c|c|c|}
\hline \multirow{2}{*}{ No } & \multirow[b]{2}{*}{ Nama Komponen } & \multirow{2}{*}{$\begin{array}{l}\text { Rumus } \\
\text { Molekul }\end{array}$} & \multirow{2}{*}{$\begin{array}{l}\text { Berat } \\
\text { Molekul }\end{array}$} & \multirow{2}{*}{$\begin{array}{l}\text { Titik } \\
\text { Didih } \\
\left.{ }^{\circ} \mathrm{C}\right)\end{array}$} & \multirow{2}{*}{$\begin{array}{c}\mathrm{Rt} \\
\text { (menit) }\end{array}$} & \multicolumn{4}{|c|}{$\%$ Area rata-rata } & \multicolumn{4}{|c|}{ Pola Fragmentasi } \\
\hline & & & & & & Maluku & Sumatera & Sulawesi & lawa & Sampel & $\begin{array}{l}\text { Base } \\
\text { Peak }\end{array}$ & Wiley Library & $\begin{array}{l}\text { Base } \\
\text { Peak }\end{array}$ \\
\hline 1 & para-eugenol & $\mathrm{C}_{10} \mathrm{H}_{12} \mathrm{O}_{2}$ & 164 & $\begin{array}{l}252,00- \\
253,00\end{array}$ & 11,222 & 44,53 & 0 & 0 & 62,27 & $\begin{array}{l}164,149,133,131, \\
121,119,103,102, \\
91,89,79,77,67, \\
55\end{array}$ & 164 & $\begin{array}{l}164,163,149, \\
137,131,122, \\
121,115,104, \\
103,94,91,81 \\
77,65,55\end{array}$ & 164 \\
\hline 2 & 3-allilguaiakol & $\mathrm{C}_{10} \mathrm{H}_{12} \mathrm{O}_{2}$ & 164 & $\begin{array}{l}252,00- \\
253,00\end{array}$ & 11,338 & 16,85 & 75,21 & 68,52 & 11,13 & $\begin{array}{l}164,149,133,131, \\
121,115,103,102, \\
91,89,81,77,65, \\
55\end{array}$ & 164 & $\begin{array}{l}164,163,149, \\
137,131,122, \\
121,115,104 \\
103,94,91,81 \\
77,65,55\end{array}$ & 164 \\
\hline 3 & \begin{tabular}{|l|} 
Trans beta-kariofilen \\
\end{tabular} & $\mathrm{C}_{15} \mathrm{H}_{24}$ & 204 & $\begin{array}{l}256,00- \\
259,00\end{array}$ & 12,202 & 6,98 & 4,36 & 3,86 & 6,26 & $\begin{array}{l}189,175,161,147, \\
133,120,109,105, \\
95,93,61,79,69, \\
65,55\end{array}$ & 69 & $\begin{array}{l}189,175,161, \\
147,133,123, \\
120,109,105,95, \\
93,81,79,69,65, \\
55\end{array}$ & 69 \\
\hline 4 & \begin{tabular}{|l|}
3,4 \\
dmetilbisikloo[4.3.0] \\
nons-3,8,-dien-7-0n
\end{tabular} & $\mathrm{C}_{|| \mid} \mathrm{H}_{14} \mathrm{O}$ & 162 & $\begin{array}{l}260,00- \\
264,00\end{array}$ & 12,495 & 0,06 & 0,11 & 0,09 & 0,15 & $162,147,119,91$ & 162 & $162,147,119,91$ & 162 \\
\hline 5 & Alfa-humulen & $\mathrm{C}_{1} \mathrm{H}_{24}$ & 204 & $\begin{array}{l}166,00- \\
168,00\end{array}$ & 12,6004 & 0,90 & 0,45 & 0,43 & 0,77 & $\begin{array}{l}147,121,107,93, \\
91,80,67,53\end{array}$ & 93 & $\begin{array}{l}147,121,107,93, \\
92,80,77,67,53\end{array}$ & 93 \\
\hline 6 & \begin{tabular}{|l|} 
Eugenol assetat \\
\end{tabular} & $\mathrm{C}_{12} \mathrm{H}_{14} \mathrm{O}_{3}$ & 206 & $\begin{array}{l}281,00- \\
285,00\end{array}$ & 13,268 & 30,54 & 19,63 & 27,01 & 16,90 & $\begin{array}{l}206,164,149,137, \\
131,121,115,105, \\
103,91,77,65,55\end{array}$ & 164 & $\begin{array}{l}206,164,149, \\
138,131,121, \\
107,103,91,89 \\
77,65,55\end{array}$ & 164 \\
\hline 7 & $\begin{array}{l}\text { 3-trideuterometoksi-4- } \\
\text { asctil-2(sH)-firanon }\end{array}$ & $\mathrm{C}_{9} \mathrm{H}_{5} \mathrm{D}_{3} \mathrm{O}_{4}$ & 159 & $\begin{array}{l}73,00 \\
\overline{\pi, 00}\end{array}$ & 13,455 & 0 & 0 & 0 & 0,11 & 159 & 159 & 159 & 159 \\
\hline 8 & (-)-a-kopsen & $\mathrm{C}_{16} \mathrm{H}_{2 \mathrm{~s}}$ & 218 & $\begin{array}{r}246,00- \\
251,00 \\
\end{array}$ & 13,495 & 0 & 0 & 0,13 & 0 & $\begin{array}{l}161,134,119,105, \\
73\end{array}$ & 161 & \begin{tabular}{|l}
$161,133,119$, \\
$105,93,81$ \\
\end{tabular} & 161 \\
\hline 9 & \begin{tabular}{|l|} 
Asam propaned ioat, \\
dibromo- \\
bis(trimetilisili)ester
\end{tabular} & $\begin{array}{c}\mathrm{C}_{9} \mathrm{H}_{18} \mathrm{Br}_{2} \mathrm{O}_{4} \\
\mathrm{Si}_{2}\end{array}$ & 404 & $\begin{array}{l}91,00 \\
-- \\
93,00\end{array}$ & 13,517 & 0,06 & 0,08 & 0 & 0,15 & 147,73 & 73 & 147,73 & 73 \\
\hline 10 & mot identified & - & $\cdot$ & & 13,794 & 0,05 & 0 & 0 & 0 & - & $\cdot$ & $\cdot$ & $\cdot$ \\
\hline 11 & \begin{tabular}{|l|}
$2,3,4$ \\
trimetoksiasetofenon \\
\end{tabular} & $\mathrm{C}_{111} \mathrm{H}_{14} \mathrm{O}_{4}$ & 210 & $\begin{array}{r}295,00- \\
297,00 \\
\end{array}$ & 15,199 & 0,04 & 0 & 0 & 0 & 195 & 195 & 210,195 & 195 \\
\hline 12 & $\begin{array}{l}\begin{array}{l}\text { Etanone, } 1-\beta, 4,4,- \\
\text { trimetoksifenil) }\end{array} \\
\end{array}$ & $\mathrm{C}_{11} \mathrm{H}_{14} \mathrm{O}_{4}$ & 210 & $\begin{array}{l}320,00 \\
-322,00 \\
\end{array}$ & 15,544 & 0 & 0,18 & 0 & 0 & $210,195,192,152$ & 195 & $\begin{array}{l}210,196,195, \\
167,152 \\
\end{array}$ & 195 \\
\hline 13 & \begin{tabular}{|l|}
$\begin{array}{l}\text { Etanone, } 1-2,4,6-6 \\
\text { trimetoksifenil) }\end{array}$ \\
\end{tabular} & $\mathrm{C}_{111} \mathrm{H}_{14} \mathrm{O}_{4}$ & 210 & $\begin{array}{l}326,00- \\
328,00\end{array}$ & 15,639 & 0 & 0 & 0 & 2,20 & $\begin{array}{l}210,196,195,177, \\
152,109,77,69, \\
65,53\end{array}$ & 195 & $\begin{array}{l}210,197,195, \\
181,180,165 \text {, } \\
152,137,122, \\
109,92,77,69, \\
63,53\end{array}$ & 195 \\
\hline
\end{tabular}

\section{Hasil Analisis Data}

Berdasarkan analisis data yang dianalisis menggunakan Cluster dapat diketahui ada dua kelompok cluster berdasar kemiripan metabolit. Cluster pertama terdiri dari minyak atsiri kuncup bunga cengkeh daerah Maluku dan Jawa yang mempunyai 11 komponen metabolit, sedangkan cluster yang kedua terdiri dari dari minyak atsiri kuncup bunga cengkeh Sumatera dan Sulawesi yang mempunyai 8 komponen metabolit. Dilihat dari tabel centroid komponen metabolit dari kedua cluster tersebut dapat dikatakan bahwa cengkeh dari daerah Maluku dan Jawa memiliki metabolit lebih banyak dengan kadar relatif senyawa mayor yang lebih tinggi daripada cengkeh dari Sumatera dan Sulawesi.

\section{KESIMPULAN}

Berdasarkan hasil penelitian yang telah dilakukan, maka diperoleh kesimpulan sebagai berikut:
1. Minyak atsiri bunga cengkeh Maluku mengandung metabolit p-eugenol; 3allilguaiakol; trans(beta)-kariofilen; 3,4dimetilbisiklo[4.3.0]nona-3,8-dien-7-on; alfahumulen; eugenol asetat; asam propanedioat,dibromo-bis(trimetilsilil)ester; 2,3,4-trimetoksiasetofenon dan satu senyawa yang belum dapat diidentifikasi.

2. Minyak atsiri bunga cengkeh Sumatera mengandung metabolit 3-allilguaiakol; trans(beta)-kariofilen; 3,4dimetilbisiklo[4.3.0]nona-3,8-dien-7-on; alfahumulen; eugenol asetat; asam propanedioat,dibromo-bis(trimetilsilil)ester dan etanone, 1-(3,4,5-trimetoksifenil).

3. Minyak atsiri bunga cengkeh Sulawesi mengandung metabolit 3-allilguaiakol; trans(beta)-kariofilen; 3,4dimetilbisiklo[4.3.0]nona-3,8-dien-7-on; alfahumulen; eugenol asetat dan (-)-a-kopaen.

4. Minyak atsiri bunga cengkeh Jawa mengandung metabolite p-eugenol; 3allilguaiakol; trans(beta)-kariofilen; 3,4- 
dimetilbisiklo[4.3.0]nona-3,8-dien-7-on; alfahumulen; eugenol asetat; asam propanedioat,dibromo-bis(trimetilsilil)ester; etanone,1-(2,4,6-trimetoksifenil) dan 3trideuterometoksi-4-asetil-2(5H)-furanon.

5. Minyak atsiri kuncup bunga cengkeh yang berasal dari Maluku (Amboyna) dan Jawa (Tawangmangu) mempunyai mutu yang lebih bagus daripada kuncup bunga cengkeh yang berasal dari Sumatera
(Padang) dan Sulawesi (Palopo) dilihat dari kelengkapan metabolit dan kadar relatif komponen mayor.

\section{SARAN}

Berdasarkan hasil penelitian, disarankan penelitian lebih lanjut mengenai penetapan kadar dari masing-masing metabolit yang terdapat pada minyak atsiri kuncup bunga cengkeh.

\section{DAFTAR PUSTAKA}

Alma, M.H., Ertas, M., Nitz, S., and Kollmannsberger, H., 2007, Chemical composition and Content of Essensial Oil from the Bud of cultivated Turkish Clove (Syzygium aromaticum L.), BioResource, 2(2), 256-269.

Anonim, 1991, Petunjuk Bercocok Tanam Cengkeh, Penerbit Kanisius, Yogyakarta, hal 15.

Ayoola, G.A., Lawore, F.M., Adelowotan, T., Aibinu, I.E., Adenipekun, E., and Coker, H.A.B., Odugbemi, T.O., 2008, Chemical analisys and antimicrobial activity of the essential oil of Syzygium aromaticum (clove), African Journal of Microbiology Res, 2, 162-166.

Chaeib, K., Hafedh, H., Tarek, Z., Amel, B., Mahmoud, R., Kacem, M., Amina, B., 2007, The chemical composition and biological activity of clove essential oil, Eugenia caryophyllata (Syzygium aromaticum L. Myrtaceae): a short review, Phytotherapy Res, 21, 501-506.

Guenter, E., 1990, Minyak Atsiri, Jilid IVB, Universitas Indonesia Press, Jakarta, hal 485.

Ghelardini, C., Galeotti, N., Mannelli, L., Mazzanti, G., Bartolini, A., 2001, Local anaesthetic activity of $\beta$-caryophyllene, Farmaco II, 56, 387-389.

Gertsch, J., Leonti, M., Raduner, S., Chen, J.Z., Xie, X, Q., Altmann, K.H., Karsak, M., Zimmer, A., 2008, Beta caryophyllene is dietary cannabioid, PNAS, 105 (26), 9099-9104.

Hussein, G., Miyashiro, H., Nakamura, N., Hattori, M., Kakiuchi, N., Shimotohno, K., 2000, Inhibitory effect of Sudanese medical plant extract on hepatitis C virus (HCV) protease, Phytoter Res, 14, 150-516.

Ketaren, S., 1985, Pengantar Teknologi Minyak Atsiri, PN. Balai Pustaka, Jakarta, hal 49-67,113, 239-259.

Kurokawa, M., Hozumi, T., Basnet, P., 1998, Purification and characterization of eugenin as antiherpesvirus compound from Geum japonicum and Syzygium aromaticum (L.) Merr. Et Perry, Food Chem, 74, 443-448.

Lee, K.G., and Shibamoto, T., 2001, Antioxidant Property of Aroma Extract Isolated from Clove Buds (Syzygium aromaticum (L.) Meer. Et Perry), food Chemistry, 74, 443-448.

Ohta, T., Watanabe, K., Moriya, M., Shirasu, Y., Kada, T., 1983, Anti-mutagenic Effect Of Cinnamaldehyde On Chemical Mutagenesis In Escherichia coli, Mutat Res, 107, 219-227.

Zheng, G.C., Kenney, P.M., Lam, L.K.T., 1992, Sesquiterpenes from clove (Eugenia caryophyllata) as potential anticarcinogenic agents, J. Nat. Prod, 53(7), 999-1003. 